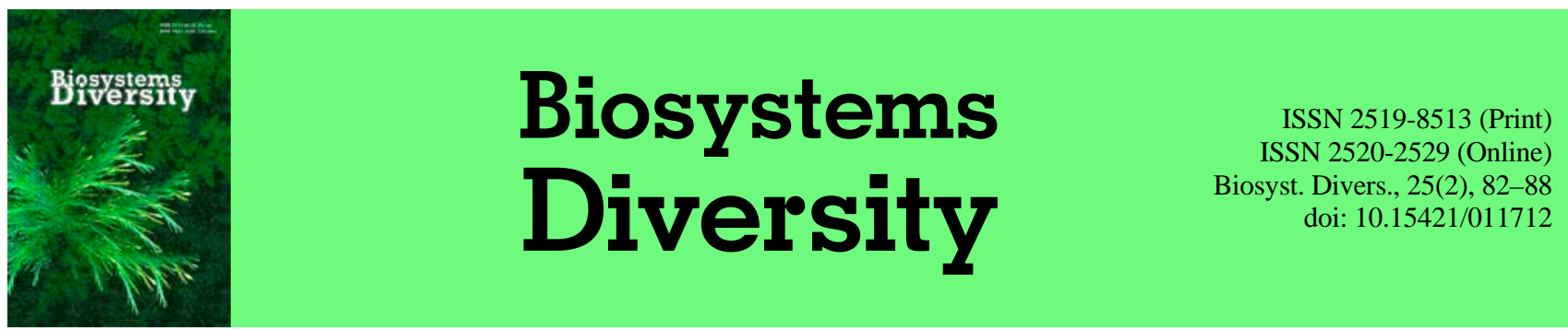

\title{
Recreational transformation of the herbaceous layer in an urban forest ecosystem of Central Podolia
}

\author{
O. I. Blinkova
}

National University of Life and Environmental Sciences of Ukraine, Kyiv, Ukraine

Article info

Received 20.04.2017

Received in revised form 11.05.2017

Accepted 13.05.2017

National University of Life and Environmental Sciences of Ukraine, Geroyiv Oborony Str., 15, Kyiv, 03041, Ukraine. Tel. +38-044-257-71-55 E-mail:

elena.blinkova@gmail.com
Blinkova, O. I. (2017). Recreational transformation of the herbaceous layer in an urban forest ecosystem of Central Podolia. Biosystems Diversity, 25(2), 82-88. doi:10.15421/011712

This article examines the impact of recreational activities on herbaceous cover of forests on the example of an urban environment in Central Podolia. The features of changes in environmental conditions of ecotypes of an urban forest have been shown through the systematic, biomorphological and ecomorphic structure of the herbaceous cover, the ratio of ecological groups, changes in type of ecological strategy of species, assessment of ecological fractions valences, and phytodiversity. We found 78 species of vascular plants. The most diverse families are Asteraceae, Poaceae and Lamiaceae. The biomorphological range of phytodiversity of the intensive recreational zone is characterized by a high proportion of adventive and ruderal species, dominance of vegetative mobile species, forming of monodominant groups and disturbed distribution of all spectrum types for coenotic morphs. Perennial hemicryptophytes dominate in the spectrum of life forms. The share of therophytes increased along the gradient of recreational transformation. Unrosellate herbal plants dominate in the structure of aboveground shoots and leaf placement, plants that don't have special modifications dominate in the structures of underground shoots. Helophytes dominated in the analysis of heliomorphic plants. Mesophytes dominated almost everywhere. The share of hydrocontrastophobes increased with a gradual removal from places of recreation. Changes in acidomorphic and nitromorphic structures of plants were not found. Types of transitional groups of ecological strategies, including CR-, CS-, and CRS-strategies prevailed. The share of patiens diminished. Exsplerents from all types of primary ecological strategies dominated. Analysis of ecological valence fractions showed that species of hemi-euryvalent and euryvalent fractions dominate among hydromorphes, hemi-euryvalent species dominate among ecogroups of scale variability humidification of soil, hemystenovalences species dominate among trophomorphes. Euryvalenct fractions were absent in soil aeration ecogroups. The overall measure of phytodiversity is at its maximum in the zone of weak recreational transformation.

Keywords: vegetation; ecomorph; biomorph; ecological valence; phytodiversity; phytoindication

\section{Рекреаційна трансформація трав'яного ярусу лісів урбоекосистем Центрального Поділля}

\author{
О. І. Блінкова
}

\section{Національний університет біоресурсів і природокористування Украӥни, Київ, Украӥна}

Охарактеризовано наслідки впливу рекреаційної діяльності на трав'яну рослинність лісів в урбоумовах на прикладі Центрального Поділля. Особливості зміни екотопів лісів урбоекосистеми показано через систематичну, біоморфологічну, екоморфічну структури трав'яного покриву, співвідношення екологічних груп, зміну типу екологічної стратегії видів, оцінку фракцій екологічних валентностей, фіторізноманіття. Виявлено 78 видів судинних рослин. Найбільше представлені родини Asteraceae, Pоасеае та Lamiaceae. Біоморфологічний спектр фіторізноманіття у зоні інтенсивного рекреаційного впливу характеризується високою часткою адвентивних і рудеральних видів, порушенням співвідношень ценоморф, формуванням монодомінантних угруповань. За спектром життєвих форм переважають багаторічні гемікриптофіти, частка терофітів поступово збільшується з посиленням інтенсивності рекреаційного впливу. За структурами надземних пагонів і розміщенням листків домінують безрозеткові трав'яні рослини, підземних пагонів - рослини, які не мають спеціалізованих видозмін. За аналізом геліоморф превалюють геліофіти. Встановлено домінування мезофітів. Із віддаленням від місць відпочинку збільшується частка гідроконтрастофобів. Зміни ацидоморф і нітроморф не виявлено. Домінують види перехідних груп екологічних стратегій (CR, CS, CRS). Аналіз фракцій екологічних валентностей показав, що за гідроморфами домінують види геміевривалентної та евривалентної фракції, шкалою змінності зволоження - гемістеновалентні види, трофоморфами - гемістенобіонтні види. За відношенням до аерації грунту відсутня евривалентна екологічна фракція. Встановлено, що узагальнена міра фіторізноманіття максимальна у зоні слабкої рекреаційної дигресії.

Ключові слова: рослинність; екоморфа; біоморфа; екологічна валентність; фіторізноманіття; фітоіндикація Вступ

За інтенсивного рекреаційного впливу на довкілля відбулися значні зміни умов існування видів. Це проявляється у за- брудненні навколишнього середовища, руйнуванні грунтового та рослинного покриву, його фрагментації, що спричиняє трансформацію екосистем. У підтриманні стабільності функціонування біосфери (Mirkin et al., 2001; Gamfeldt et al., 2013; Lavrov 
et al., 2015) визначальну роль відіграють ліси (завдяки значній площі, ємності, тривалості розвитку, стійкості, продуктивності, складності структури). Фітоценози чутливо реагують на зміну екологічних режимів та віддзеркалюють зміни структури екосистем на різних рівнях організації живої матерії (Ramenskii, 1971; Jenkins and Parker, 2000; Mirkin et al., 2001; Bondaruk, 2008; Golay et al., 2016; Vakhlamova et al., 2016).

В Україні рекреація - один із головних антропогенних чинників. Вона часто зумовлює суттєву трансформацію, а іноді й деградацію лісової екосистеми (Brygadyrenko, 2015). Внаслідок рекреації механічний вплив проявляється у вигляді витоптування підстилки, ущільнення поверхневого шару грунту, механічного пошкодження рослин деревостану та трав'яного ярусу (Pickering and Hill, 2007; Bondaruk, 2008; Lavrov et al., 2015). Внаслідок розмежовування стежками та іншими витоптаними ділянками нижніх ярусів відбувається фрагментація фітоценозів, зміна їх видового складу та будови. Зручний, актуальний та інформативний об'єкт дослідження комплексного впливу людини рослинний покрив зелених зон міст (Kuznetsov et al., 2015; Oduber et al., 2015; Gunnarsson et al., 2017). Найчутливіший компонент для оцінювання наслідків рекреації - трав'яний ярус лісів зелених зон міст (Werner, 2011). Останнім часом зросла важливість досліджень структур трав'яного покриву, тому питання порівняння їх на градієнті антропогенної трансформації давно складають особливу сферу питань екології рослин (Gibson et al., 2000; Gilliam, 2007; Murat et al., 2008; Elliott et al., 2015). Отже актуальність дослідження не викликає сумніву.

Мета цього дослідження - оцінити зміни структури трав'яного ярусу залежно від інтенсивності рекреаційного впливу.

\section{Матеріал і методи досліджень}

Обстежено територію одного з найбільших міст Центрального Поділля - Вінниці. Це обласний центр на правобережжі Дніпра, у лісостеповій зоні України. Місто розташоване на обох берегах середньої течії Південного Бугу (майже на 10 км). Площа міста становить 6094 га. Перші відомості про природу та історичний розвиток території досліджень наведені В. Марчинським. У минулому територія міста була вкрита грабово-дубовими лісами та іншими рослинними угрупованнями формації Querceta roboris. За сучасним геоботанічним районуванням територія належить до Літинського геоботанічного району Центрально-Подільського округу Подільсько-Бессарабської підпровінції Східноєвропейської провінції Європейської широколистяної області. Рослинність представлена типовими видами західноєвропейського помірно вологого та помірно теплого клімату, а також видами континентального клімату.

Обстежно зелену зону міста на території ДП «Вінницьке лісове господарство» Вінницького лісництва в одному з найпо-

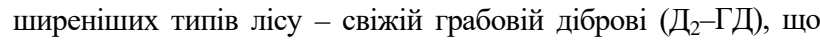
сформувалася на темно-сірих опідзолених грунтах та чорноземах опідзолених. Судячи із фондових документів лісовпорядкування, ці ліси певною мірою відображають характер рекреаційної дигресії міст Центрального Поділля. Шляхом рекогносцирувальних обстежень на ідентичних за деревостанами ділянках закладено екологічний профіль із чотирьох пробних площ (ПП) поблизу організованих місць відпочинку навколо озера Соцьке 3 різним рекреаційним впливом: ПП1 - інтенсивний вплив, ПП2 середній, ППЗ - помірний, ПП4 - слабкий вплив. Рекреаційне навантаження (стадії трансформаціі) на лісову екосистему оцінювали за станом деревостану та поверхні грунту, характером відновлення рослин, проективним покриттям, ступенем витоптування трав'яного ярусу, характером та інтенсивністю механічного пошкодження дерев і чагарників тощо.

Польові дослідження на екопрофілі проводили за допомогою загальноприйнятих в екології та геоботаніці методів (Didukh, 1994; Mirkin et al., 2001). Латинські назви таксонів рослинності наведено за Mosyakin and Fedoronchuk (1999). Біоморфологічна структура наведена за Serebrjakov (1962). Еко- морфічний аналіз здійснювали за Tarasov (2005). Типи екологічних стратегій описували за схемою Раменського - Грайма (Grime, 1977). Життєві форми рослин наведено за Раункієром (Raunkiaer, 1934; Mirkin et al., 2001). Проективне покриття видів оцінювали за шкалою Mirkin et al. (2001). Індекс адвентизації встановлювали як частку у відсотках заносних видів від загальної чисельності видів на певній тестовій ділянці. Стан поверхневого шару грунту характеризували за Polyakov (2009). Зміну екологічних умов виявляли за екологічною структурою трав'яного ярусу, використовуючи відповідні шкали (Didukh, 1994). Екологічну валентність видів встановлювали за Jukova et al. (2010). Індекс толерантності (It) розраховували як сумму екологічних валентностей, поділену на суму шкал. Стенобіонти (СБ) - види, в яких It $<0,34$, гемістенобіонти (ГСБ) It $<0,46$, мезобіонти (МБ) - It $<0,56$, геміеврибіонти (ГЕБ) It $<0,67$, еврибіонти (ЕБ) - It $>0,67$.

Обробку результатів досліджень здійснювали за показниками фіторізноманіття, дотримуючись рекомендацій Magurran (2004): розраховували індекси різноманіття Шеннона, Менхініка, Сімпсона та Пієлу.

\section{Результати}

Видовий склад трав'яної рослинності на дослідженому екопрофілі представлений 78 видами судинних рослин, які належать до 73 родів 27 родин. Спектр 10 провідних родин трав'яних рослин формують: Asteraceae - 23 види, або $29,4 \%$ від загальної кількості видів; Роасеае, Lamiaceae - 6, або 7,7\%; Fabaceae та Ranunculaceae - 4, або 5,1\%; Caryophyllaceae, Polygonaceae, Scorphulariaceae - по 3 види, або $3,8 \%$; 7 родин містять по 2 види, або 2,2\%, 12 родин мають по одному виду (1,5\%). На екопрофілі види родини Asteraceae домінують на порушених місцезростаннях (ПП1). Друге та третє місця поділяють родини Poaceae, Lamiaceae, Fabaceae та Ranunculaceae.

На ПП1 загальне проективне покриття становить 55,2\%; $12,5 \%$ - рудеральні та адвентивні види (Chelidonium majus L., Malva sylvestris L., Sonchus arvensis L., Stenactis annua L., Taraxacum officinale L., Rumex confertus L. тощо). Стадія рекреагенної дигресії грунту -4 .

На ПП2 загальне проективне покриття більше - 71,5\%, нелісові види складають 7,2\%. Стадія рекреагенної дигресії грунту -3.

На ППЗ загальне проективне покриття знижується до $85,5 \%$, домінують також лісові види, але подекуди з'являються нехарактерні для даного типу лісу Dactylis glomerata L., Mercurialis perennis L., Plantago major L., Senecio vulgaris L. тощо. Грунт деградує на рівні дві стадії дигресії.

На ПП4 загальне проективне покриття становить 95,5\%; домінують лісові види, зокрема Asarum europaeum L., Carex disticha L., Galium aparine L., M. perennis, Polygonatum multiflorum L., Polygonum aviculare L., Pulmonaria officinalis L. тощо. Стадія рекреагенної дигресії грунту -1 .

Індекс адвентизації складає на екопрофілі 23,1\%, 20,5\%, $20,5 \%$ та $15,1 \%$ на ПП $1, \Pi П 2$, ППЗ та ПП 4 . Відповідно до отриманих результатів установлено для досліджених ПП1ПП4 такі стадії рекреаційної трансформації: ПП1 - IV, ПП2 III, ППЗ - II, ППП1 - I.

Біоморфологічний спектр трав'яної рослинності свідчить про особливості пристосування рослинного покриву до рекреаційних змін (табл. 1). Зокрема, за тривалістю життєвого циклу багаторічні трави домінують на ПП2-ПП4. Однорічників найменше виявлено за помірного та слабкого рекреаційного впливу (15,6\% на ПП4, 12,5\% на ПП3). Частка дворічників коливалась у межах 6,7-13,2\%.

Аналіз структури надземних пагонів як характеристики, що визначає екологічні умови місцезростань, показав, що на всіх ПП домінують безрозеткові види $(61,9-75,6 \%)$. Частка видів із розетковими пагонами в декілька разів менша - 8,4$23,8 \%$. Види 3 повзучими пагонами були представлені най- 
менше (11,1-18,7\%; Cuscuta europaea L., Convolvulus arvensis L., Galium aparine L., Glechoma hederacea L., Oxalis acetosella L., $P$. aviculare тощо). За структурою підземних пагонів на всіх ППП переважають види без утворень (52,3-62,2\%). Найбільший внесок довгокореневищних видів (Achillea millefolium L., Ambrosia artemisiifolia L., Artemisia absinthium L., Calamagrostis epigejos L., Chelidonium majus L., Poa pratensis L., S. arvensis тощо) зафіксовано на ПП1, що спричинено особливостями пристосування видів до наслідків рекреаційної діяльності. Коренепаросткові види найменше представлені на ПП (4,6-6,7\%).

Таблиця 1

Біо- та екоморфологічний спектр трав'яної рослинності

\begin{tabular}{|c|c|c|c|c|}
\hline \multirow{5}{*}{ Ознаки життєвих форм } & \multicolumn{4}{|c|}{ Розподіл на екопрофілі } \\
\hline & ПП1 & ПП2 & ППЗ & $\Pi \Pi 4$ \\
\hline & \multicolumn{4}{|c|}{ Стадії рекреаційної трансформації } \\
\hline & IV & III & II & I \\
\hline & \multicolumn{4}{|c|}{ Частка видів, \% } \\
\hline \multicolumn{5}{|c|}{ Тривалість життєвого циклу } \\
\hline Однорічні & 40,3 & 28,8 & 12,5 & 15,6 \\
\hline Дворічні & 13,2 & 9,0 & 10,4 & 6,7 \\
\hline Багаторічні & 46,5 & 62,2 & 77,1 & 77,7 \\
\hline \multicolumn{5}{|c|}{ Структура надземних пагонів } \\
\hline Повзучі & 14,3 & 17,8 & 18,7 & 11,1 \\
\hline Розеткові & 23,8 & 22,2 & 8,4 & 13,3 \\
\hline Безрозеткові & 61,9 & 60,0 & 72,9 & 75,6 \\
\hline \multicolumn{5}{|c|}{ Структура підземних пагонів } \\
\hline Довгокореневищні & 30,9 & 24,4 & 25,0 & 22,2 \\
\hline Короткокореневищні & 11,9 & 25,5 & 10,4 & 8,9 \\
\hline Коренепаросткові & 4,9 & 4,6 & 8,3 & 6,7 \\
\hline Без утворень & 52,3 & 55,5 & 56,3 & 62,2 \\
\hline \multicolumn{5}{|c|}{ Життєві форми за Х. Раункієром } \\
\hline Терофіти & 28,4 & 31,1 & 22,9 & 17,7 \\
\hline Хамефіти & 4,9 & 4,4 & 6,3 & 8,9 \\
\hline Гемікриптофіти & 54,8 & 57,8 & 60,4 & 57,8 \\
\hline Криптофіти & 11,9 & 6,7 & 10,4 & 15,6 \\
\hline \multicolumn{5}{|c|}{ Геліоморфи } \\
\hline Геліофіти & 66,6 & 44,4 & 31,3 & 26,7 \\
\hline Геліосціофіти & 23,8 & 26,7 & 20,8 & 20,0 \\
\hline Сціогеліофіти & 9,6 & 17,8 & 25,0 & 22,2 \\
\hline Сціофіти & 0,0 & 11,1 & 22,9 & 31,1 \\
\hline \multicolumn{5}{|c|}{ Ценоморфи } \\
\hline Галофіти & 2,4 & 0,0 & 0,0 & 0,0 \\
\hline Акванти & 2,4 & 0,0 & 0,0 & 0,0 \\
\hline Сильванти & 23,8 & 31,1 & 50,0 & 66,7 \\
\hline Пратанти & 23,8 & 20,0 & 20,9 & 6,6 \\
\hline Степанти & 2,4 & 4,4 & 0,0 & 0,0 \\
\hline Рудеранти & 45,2 & 44,5 & 29,1 & 26,7 \\
\hline Індекс адвентизації, \% & 25,5 & 19,8 & 16,1 & 15,1 \\
\hline
\end{tabular}

Аналіз життєвих форм показав, що на екопрофілі майже половина всіх представлених видів - гемікриптофіти $(54,8$ $60,4 \%$ ). Суттєвий також внесок терофітів. Варто зауважити, що найменший внесок терофітів зафіксовано на ПП4. Представленість хамефітів зростає за градієнтом рекреаційної трансформації ПП від 4,9\% (ПП1) до 8,9\% (ПП4). Максимальний внесок криптофітів виявився на ПП4 (Galeobdolon luteum Huds., Paris quadrifolia L., P. multiflorum, Stellaria holostea L. тощо).

Розподіл за геліоморфами показав, що домінують на екопрофілі геліофіти, максимальна частка яких зафіксована на ПП1 (66,6\%), натомість мінімальна - на ПП4 (26,7\%). Частка сціогеліофітів на градієнті рекреаційної трансформації збільшується з 9,6\% (ПП1) до 22,2\% (ПП4). Представленість сціофітів також максимальна на ПП4 (Dryopteris filix-mas (L.) Schott, P. multiflorum, P. quadrifolia, Orchis coriophora L. тощо) і $€$ типовою для лісових ценозів. На ПП1 сціофіти відсутні.

Аналіз за ценоморфами показав, що на досліджених ділянках домінують сильванти та рудеранти. Максимальна частка сильвантів зафіксована на території із слабким рекреаційним впливом, I стадією трансформації $(66,7 \%)$, натомість участь рудерантів $(26,7 \%)$ і пратантів $(6,6 \%)$ тут найменша. Найбільший $(23,8 \%)$ внесок пратантів (зокрема, Acroptilon repens (L.) DC., Carex pilosa Scop., Trifolium pratense L., Campanula glome- rata L. тощо) та рудерантів (45,2\%; зокрема, Bromus squarrosus L., Bromus hordeaceus L., Berteroa incana (L.) DC., D. glomerata, Nardus stricta L. тощо) зафіксовано на ПП1. Участь галофітів і аквантів виявилася однаковою на ПП1 (по 2,4\%). Представленість степантів становила $2,4 \%$ та 4,4\% на ПП1 та ПП2 відповідно. Аналіз індексу адвентизації на екопрофілі свідчить про антропогенну трансформацію екотопів: $25,5 \%, 19,8 \%, 16,1 \%$ i $15,1 \%$. Серед адвентивних видів переважали північноамериканські інвазійні види - Cannabis ruderalis Janisch., Conyza canadensis (L.) Cronquist, Ambrosia artemisiifolia L., Stenactis annua (L.) Cass., Oenothera biennis L., Ceratocephala testiculata Crantz (Roth), Asclepias syriaca L. тощо. Серед аборигенних антропофітів домінували Achillea millefolium L., Elytrigia repens (L.) Nevski, Rumex confertus Willd., Convolvulus arvensis L., Artemisia vulgaris L., P. major та інші.

Таблиця 2

Розподіл видів трав'яних рослин (\%) за екологічними групами

\begin{tabular}{|c|c|c|c|c|}
\hline \multirow{2}{*}{ Екологічні групи } & \multicolumn{4}{|c|}{ Розподіл на екопрофілі } \\
\hline & ПП1 & ПП2 & ППЗ & ПIП4 \\
\hline \multicolumn{5}{|c|}{ Гідроморфи, Нd } \\
\hline Гігрофіти & 2,7 & 2,2 & 6,7 & 7,0 \\
\hline Гігромезофіти & 29,2 & 27,4 & 31,9 & 31,8 \\
\hline Мезофіти & 39,0 & 45,5 & 51,1 & 54,5 \\
\hline Субмезофіти & 24,3 & 22,7 & 8,2 & 4,5 \\
\hline Субксерофіт & 4,8 & 2,2 & 2,1 & 2,2 \\
\hline \multicolumn{5}{|c|}{ Змінність зволоження, fH } \\
\hline Гідроконтрастофоби & 2,4 & 6,8 & 6,4 & 9,1 \\
\hline Гемігідроконтрастофоби & 31,7 & 38,6 & 57,4 & 61,4 \\
\hline Гемігідроконтрастофіли & 43,9 & 36,3 & 29,8 & 25,0 \\
\hline Гідроконтрастофіли & 14,6 & 11,4 & 4,3 & 2,3 \\
\hline Гіпергідроконтрастофіли & 7,4 & 6,9 & 2,1 & 2,2 \\
\hline \multicolumn{5}{|c|}{ Ацидоморфи, Rc } \\
\hline Перацидофіли & 2,4 & 0,0 & 0,0 & 0,0 \\
\hline Ацидофіли & 7,3 & 4,5 & 4,3 & 4,5 \\
\hline Субацидофіли & 60,9 & 63,6 & 61,7 & 59,1 \\
\hline Нейтрофіли & 26,8 & 31,9 & 34,0 & 36,3 \\
\hline Базофіли & 2,6 & 0,0 & 0,0 & 0,0 \\
\hline \multicolumn{5}{|c|}{ Узагальнений сольовий режим, $\mathrm{Tr}$} \\
\hline Семіоліготрофи & 2,4 & 0,0 & 0,0 & 0,0 \\
\hline Мезотрофи & 9,7 & 15,9 & 21,2 & 27,2 \\
\hline Семіевтрофи & 60,9 & 61,4 & 70,2 & 63,6 \\
\hline Евтрофи & 17,1 & 18,2 & 8,6 & 9,2 \\
\hline Субглікотрофи & 7,3 & 2,2 & 0,0 & 0,0 \\
\hline Глікотрофи & 2,6 & 2,3 & 0,0 & 0,0 \\
\hline \multicolumn{5}{|c|}{ Нітроморфи, $\mathrm{Nt}$} \\
\hline Субанітрофіли & 4,8 & 2,2 & 4,3 & 4,5 \\
\hline Гемінітрофіли & 39,0 & 38,6 & 31,9 & 29,5 \\
\hline Нітрофіли & 43,9 & 45,5 & 48,9 & 52,3 \\
\hline Еунітрофіли & 12,3 & 13,7 & 14,9 & 13,7 \\
\hline \multicolumn{5}{|c|}{ Аероморфи, Ае } \\
\hline Субаерофіли & 43,9 & 38,6 & 19,1 & 18,2 \\
\hline Геміаерофоби & 43,9 & 50,0 & 65,9 & 75,0 \\
\hline Субаерофоби & 12,2 & 11,4 & 15,0 & 6,8 \\
\hline
\end{tabular}

Характер гідроморф відображає відношення видів до водного режиму. Про рекреаційне порушення водного режиму грунту на екопрофілі свідчить аналіз гідротопу. Із посиленням рекреаційного впливу на ПП збільшується частка субмезофітів (A. millefolium, Echium vulgare L., T. officinale тощо) з 4,5\% до $24,3 \%$ та субксерофітів $32,2 \%$ до $4,8 \%$. Натомість частка мезофітів, гігромезофітів та гігрофітів зменшується: 3 54,5\% до $39,0 \%$, $з 31,8 \%$ до $29,2 \%$ та $37,0 \%$ до 2,7\%, відповідно. Загалом провідна роль належить мезофітам і гігромезофітам.

Із віддаленням від рекреаційних місць відпочинку (ПП1ППП4) збільшується частка гідроконтрастофобів з 2,4\% до 9, $1 \%$. Внесок гемігідроконтрастофобів також збільшується майже вдвічі на ПП4 (61,4\%) порівняно з ПП1 (31,7\%). Нерівномірність зволоження кореневмісного шару грунту на екопрофілі найбільше виражена на ділянках інтенсивного та середнього рекреаційного впливу. Зокрема, частка гемігідроконтрастофілів становить $43,9 \%$ та $36,3 \%$ на ПП1 та ПП2, відповідно. Внесок гідроконтрастофілів та гіпергідроконтрастофілів на цих ПП був 
максимальним на екопрофілі. Такий розподіл екогруп за відношенням до змінності зволоження пояснюється нестійким і нерівномірним зволоженням кореневмісного шару грунту за інтенсивного та середнього рекреаційного впливу. Аналіз трофотопу щодо кислотного режиму грунту показав, що на екопрофілі домінують субацидофіли $(60,9-59,1 \%)$. Майже вдвічі менший внесок у нейтрофілів (26,8-36,3\%). Тенденцій щодо зміни ацидоморфічного складу не виявлено. Аналіз трофотопу за загальним сольовим режимом свідчить про домінування семіевтрофів (60,9-63,6\%; G. hederacea, Galinsoga parviflora Cav., Malva sylvestris L., P. multiflorum, Poa annua L., Sisymbrium officinale (L.) Scop., S. annua, Galeopsis speciosa Mill. тощо). Глікотрофи та субглікотрофи присутні тільки на ПП1 (2,6\%, 7,3\%) та ПП2 (2,3\%, 2,2\%).

Важлива характеристика едафічного режиму - вміст у грунті доступних форм азоту. За нітратним режимом (Nt) yсі грунти ПП належать до відносно забезпечених мінеральним азотом (0,3-0,4\%). На екопрофілі домінують гемінітрофіли та нітрофіли. Мінімільну частку складають субанітрофіли $(2,2-$ 4,8\%; A. arvensis, B. incana, Viola canina L. тощо). Тенденцій щодо зміни нітроморфічного складу не виявлено.

Аналіз екогруп за відношенням до аерованості грунту показав, що на екопрофілі представлені лише субаерофіли, геміаерофоби та субаерофоби. Серед представлених екогруп домінували рослини помірно аерованих грунтів (геміаерофоби), частка яких помірно збільшувалася у міру віддалення від місць відпочинку з 43,9\% на ПП1 до 75,0\% на ПП4. Максимальна частка субаерофобів становила $15,0 \%$ на ППЗ, тоді як максимальна частка субаерофілів складала $38,6 \%$ (ПП2).

Оцінювання фракцій екологічних валентностей видів здійснене за розподілом гідроморф, змінністю зволоження, трофоморф і аероморф. За гідроморфами на екопрофілі домінують види геміевривалентної та евривалентної фракції (24,4-31,8\%, 23,0-43,2\%) (рис. 1). Частка видів стеновалентної фракції зменшується на градієнті рекреаційної трансформації. Стенобіонтні види відсутні на ПП1. Внесок мезобіонтних видів майже однаковий на ПП (6,89,7\%). За шкалою змінності зволоження домінували види гемістеновалентної фракції, внесок яких складав 31,9-41,5\% (рис. 2).

Другою за домінуванням виявилася група видів мезовалентної фракції, розподіл яких майже однаковий на екопрофілі (25,0-29,5\%). Еврибіонтні види були відсутні на ділянках середнього та помірного рекреаційного впливу. Натомість частка стенобіонтних видів на цих ділянках тут максимальна (17,0-22,7\%). Аналіз екологічних валентностей трофоморф показав, що домінують гемістенобіонтні види (27,3-40,9\%), максимальна частка яких зафіксована на ПП4 (рис. 3). Частка евривалентної фракції, навпаки, зменшувалась уздовж градієнта та становила лише 4,6\% на ПП4. Розвиток мезобіонтних видів виявився майже однаковим на ПП2 $(34,1 \%)$ та ПП4 $(36,3 \%)$ Мінімальний внесок стеновалентної фракції зафіксовано на ПП1 (9,7\%).

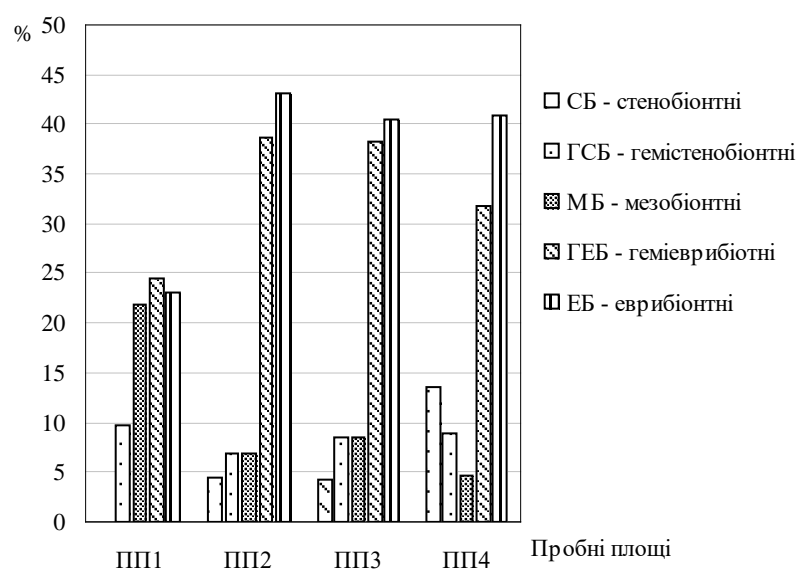

Рис. 1. Співвідношення видів до водного режиму грунтів (Hd) за індексом екологічної толерантності

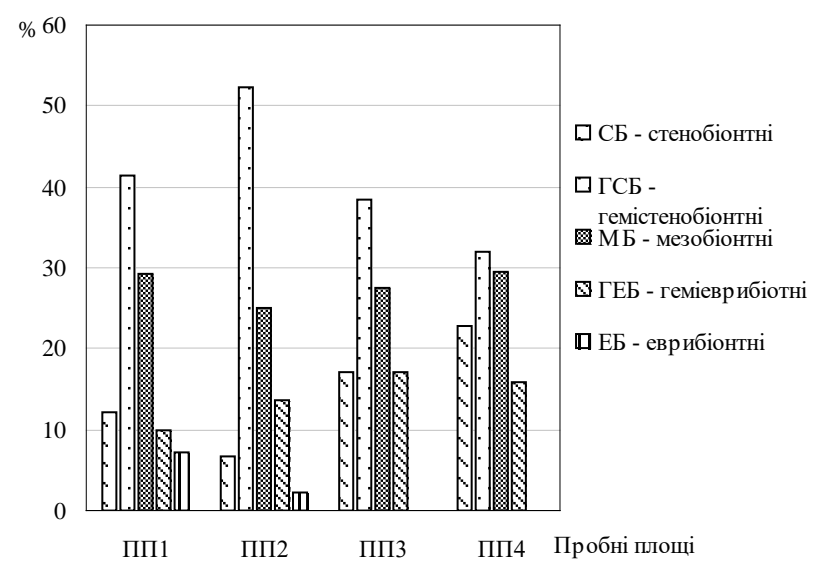

Рис. 2. Співвідношення видів до змінності зволоження (fH) за індексом екологічної толерантності

Оцінювання фракцій екологічних валентностей за аероморфами показало, що частка стенобіонтних видів поступово збільшується з 29,3\% (ПП1) до 47,7\% (ПП4), натомість внесок гемістенобіонтних і мезобіонтних поступово зменшується (рис. 4). Найменше на екопрофілі виявлено геміеврибіонтних видів (4,9$2,1 \%$ ). Варто зауважити, що за відношенням до аерації грунту на екопрофілі відсутня евривалентна екологічна фракція.

Оцінювання типів екологічних стратегій рослин показало, що на екопрофілі домінують види з перехідних груп екологічних стратегій (рис. 5).

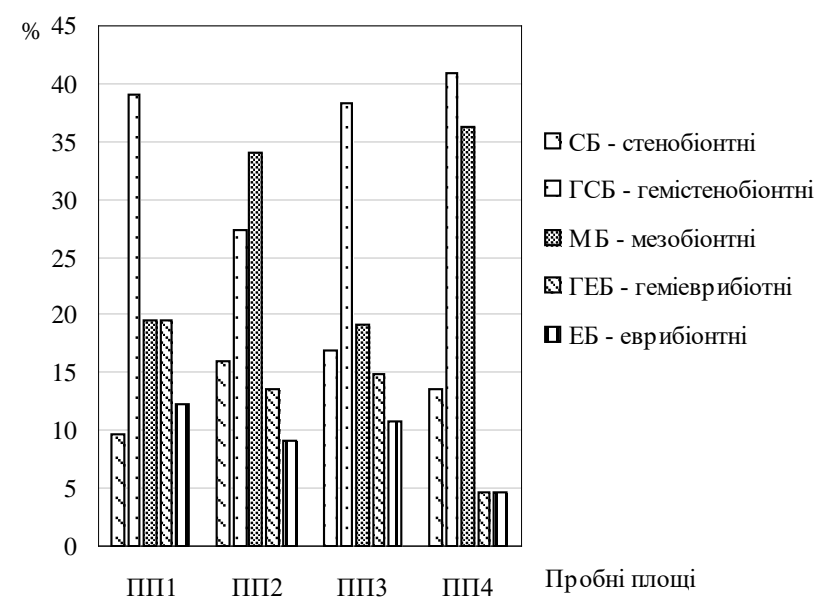

Рис. 3. Співідношення видів до узагальненого сольового режиму грунтів (Tr) за індексом екологічної толерантності

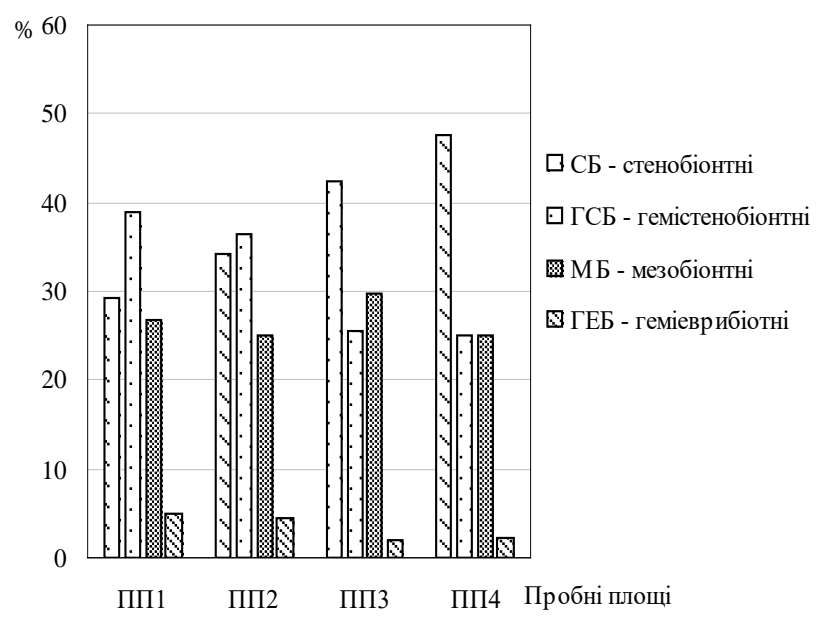

Рис. 4. Співідношення видів до аерованості грунту (Ае) за індексом екологічної толерантності 
Максимальний внесок видів із CS-стратегією становив 36,4\% на ПП4, натомість мінімальне значення сягало лише 7,2\% на ПП1. Частка видів із CR-стратегією була майже однаковою на екопрофілі (8,3-9,5\%; Lysimachia vulgaris L., S. holostea, U. dioca, M. muralis, T. pratense тощо). Виявлено тенденцію до збільшення частки видів зі змішаним типом стратегії (CRS; B. incana, G. parviflora, P. aviculare, Plantago major L., P. lanceolata L., Xanthium strumarium L., C. тајus тощо) на більш рекреаційно трансформованих ділянках. Серед видів із первинним типом екологічної стратегії превалюють експлеренти (11,3-28,5\%; Echinochloa crusgalli (L.) P. Beauv., S. vulgaris, Sisymbrium officinale (L.) Scop., $U$. dioca тощо). Віоленти на екопрофілі становили лише 4,4-6,8\%. Частка патієнтів збільшується 3 4,8\% (ПП1) до 13,6\% (ПП4) (наприклад, A. arvensis, G. aparine, G. luteum, P. multiflorum, $P$. quadrifolia, $V$. angustifolia тощо).

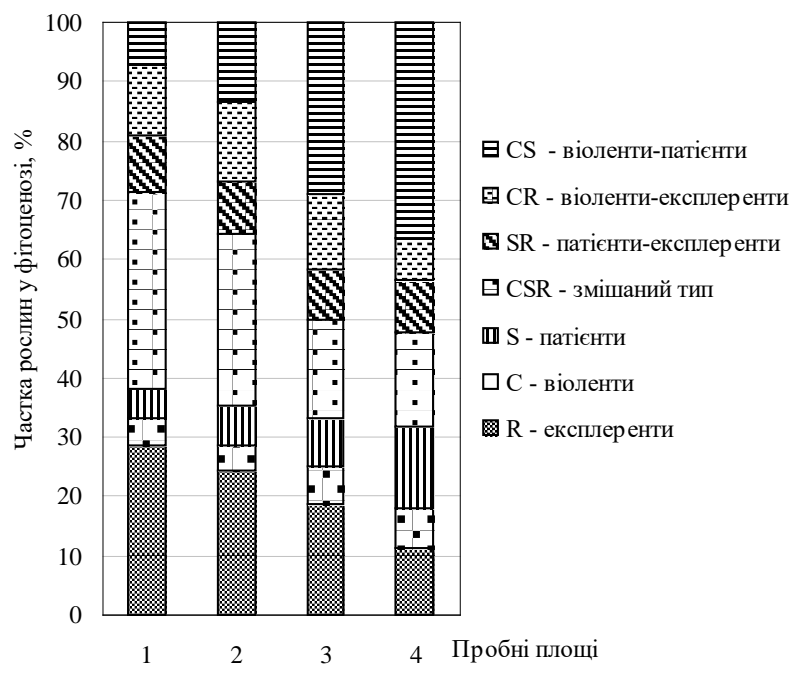

Рис. 5. Розподіл видів трав'яного ярусу на екопрофілі за типами екологічних стратегій

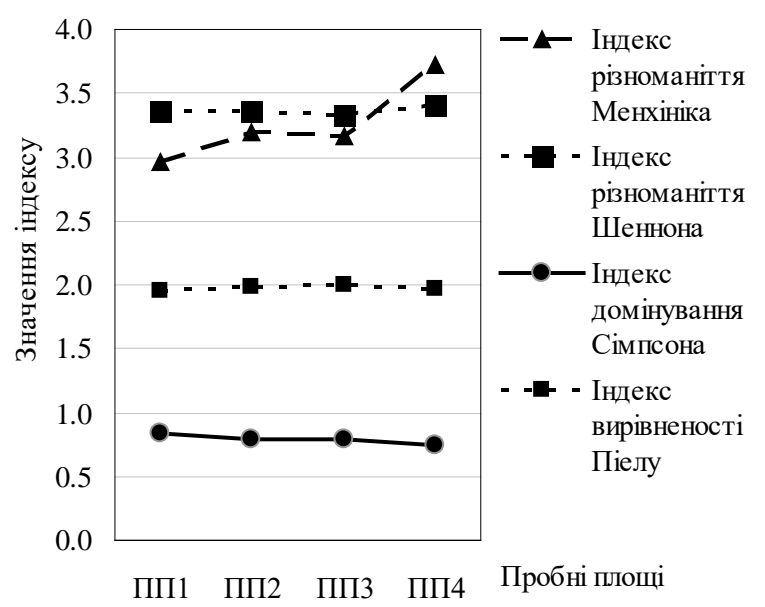

Рис. 6. Значення індексів фіторізноманіття на екопрофілі

Оцінювання індексів фіторізноманіття на екопрофілі показало, що найвищі значення індексів Менхініка та Шеннона притаманні для ділянки із слабким рекреаційним впливом (рис. 6). Відповідні значення для ділянок із середнім і помірним рекреаційним впливом майже однакові. Найнижчі значення зафіксовано для ПП1, де найбільша участь у ценозі адвентивних і рудеральних видів рослин. Екологічні умови на цій ділянці сприятливі лише для кількох основних видів-домінантів. За оцінкою індексу домінування Сімпсона встановлено, що в цілому рівень домінування для трав'янистих рослин високий для ПП1-ППЗ, найнижчі значення притаманні для ПП4. Це свідчить про те, що на більш трансформованих ділянках умови сприятливі лише для певних видів рослин (A. artemisiifolia, D. glomerata, P. major, T. officinale, S. arvensis, S. аппиа тощо), а решта перебувають у пригніченому стані. Дані щодо спектра складності фіторізноманіття на екопрофілі як рівномірності розподілу особин за видами (вирівняність за Пієлу) - майже протилежні домінуванню.

\section{Обговорення}

У світовому масштабі 6,5\% лісів становлять ліси зеленої зони навколо міст (Wang et al., 2009). Аналіз наукової літератури показав, що в контексті зростаючого урбанізаційного впливу структура лісів порушується, ставлячи під загрозу здатність міських лісів до забезпечення екосистемних послуг (Reier et al., 2005; Aerts and Honnay, 2011; Davies et al., 2011; Nagaike, 2012; Livesley et al., 2016). Рекреаційна активність спричиняє суттєву трансформацію у структурі фітоценозу (McKinney, 2002; Golay et al., 2016). Серед усіх структурних елементів урбоекосистеми трав'яна рослинність - чуттєвий біондикатор змін екологічних умов, тому питання рекреаційної трансформації трав’яного ярусу в містах давно привертають увагу науковців. Одна з основних проблем - зникнення типових видів і поява адвентивних і рудеральних видів. Дослідження показали, що адвентивні рослини швидко стають домінуючими видами, спричиняючи не тільки порушення структури трав'яного шару, а і зменшення біорізноманіття в цілому (Ehrenfeld et al., 2001; Godefroid and Koedam, 2003; Cooper et al., 2005; Celesti-Grapow et al., 2006; Campione et al., 2012; Farmer et al., 2016). Це пояснюється здатністю нехарактерних видів рослин змінювати грунтові умови, збільшувати рН, вміст азоту тощо (Ehrenfeld et al., 2003; Ladd, 2016). Інші автори теж доводять, що у порушених лісах в умовах міста суттєво збільшується частка інвазійних і адвентивних видів порівняно з природними лісами (Vidra et al., 2007; Dolan et al., 2011; Brady et al., 2016). Наші результати показали, що саме на ділянках 3 інтенсивним і середнім рекреаційним впливом індекси адвентизації $(25,5 \%, 19,8 \%)$ та частка рудерантів $(45,2 \%, 44,5 \%)$ набагато вищі порівняно 3 ділянками помірного та слабкого впливу.

Для адекватного оцінювання наслідків рекреаційної діяльності на трав'яний ярус важливе встановлення інтенсивності рекреаційного впливу, оскільки залежно від стадії рекреаційної трансформації змінюється співвідношення ознак життєвих форм рослин у біоморфологічному та екоморфічному спектрі. Деякі автори вказують, що на високих стадіях рекреаційної трансформації частка однорічних рослин суттєво збільшується порівняно з багаторічними, порушуються структури надземних і підземних пагонів (Bondaruk, 2008). При цьому збільшення кількості видів за інтенсивної рекреаційної трансформації відбувається за рахунок збільшення внеску саме однорічних рослин (Gonrad and Romane, 2005). Домінування видів із довгокореневищними підземними пагонами та видів із повзучими надземними пагонами пояснюяться адаптацією рослин до сформованих порушених грунтових умов.

Інша важлива адаптивна здатність рослин нижніх ярусів лісів - зміна життєвої форми за антропогенної трансформації лісових екосистем. Antos and Zobel (1984) зазначали, що зміна представленості життєвих форм у фітоценозі характерна для гетерогенного лісового середовища. Це збігається з відомими даними щодо збільшення внеску терофітів у антропогенно трансформованих екотопах (Burda, 2006). Установлено також зменшення внеску криптофітів уздовж градієнта рекреаційної трансформації (Williams et al., 2005).

Екоморфи відображають ставлення організмів до екологічних чинників. За антропогенної трансформації фітоценозу екоморфи створюють основу для оцінювання його структури, стійкості та різноманіття. Аналіз різних екологічних груп трофотопу за рекреаційного впливу у певних типах лісів показав, що значне варіювання внеску різних екогруп, зокрема гідроморф, трофоморф і аероморф характерне тільки для суттєво порушених ділянок, де наявні місця для відпочинку, лісові доріжки, кострища тощо. Для менш трансформованих ділянок різниця у співвідношенні екогруп несуттєва (Roovers et al., 
2004; Roovers et al., 2005; Murat et al., 2008). Окрім того, слід зауважити, що в умовах зеленої зони міста виявлено не тільки зміну у внеску кожної екогрупи, а і процеси ксерофітизації та десильватизації (Bondaruk, 2008).

Важливий індикатор різноманіття рослин щодо впливу абіотичних чинників - екологічна валентність видів. Jukova et al. (2010) показали, що для природних лісів характерне домінування стеновалентних і гемістеновалентних фракцій за едафічними умовами. За відношенням видів до водного режиму грунту та змінності зволоження евривалентна фракція може бути відсутня. За середньої трансформації екотопу суттєво збільшується внесок мезовалентних видів та видів з індексом толерантності понад 0,56. Такі висновки збігаються 3 даними щодо розподілу видів за індексом екологічної валентності. Результати свідчили про особливості зміни фракцій екологічних валентностей за аероморфами: поступове збільшення частки стенобіонтних видів та відсутність евривалентної екологічної фракції.

Приуроченість рослин до певного екотопу відображає тип їх екологічної стратегії, яка змінюється впродовж усього онтогенезу особин (Grime, 1977; Mirkin et al., 2001). На останніх стадіях антропогенної трансформації характерне домінування видів із перехідними та змішаними типами стратегій (Prevosto et al., 2011; Huseinova et al., 2013). Karel (1993) показав, що значення індексів різноманіття видів та екологічних груп знижується за посилення рекреаційного впливу. Gibson et al. (2000) встановили, що суттєво змінюється таксономічна та екологічна структура трав'яного шару лісових екосистем за інтенсивної рекреації. 3 посиленням рекреаційного впливу суттєво знижується також узагальнена міра фіторізноманіття (Beckline and Yujun, 2014).

Дослідження структури трав'яного ярусу лісів урбоекосистеми дозволяють зробити висновок про те, що ступінь трансформації фіторізноманіття знаходиться в тісному зв'язку з ін.тенсивністю рекреаційного впливу. Ці питання потребують подальших досліджень.

\section{Висновки}

Трав’яний ярус лісів урбоекосистеми зазнає широкого спектра прямого та опосередкованого порушення екологічних умов, спричинених рекреацією. Аналіз еко- та біоморфологічного спектра рослинності зеленої зони м. Вінниця характеризується типовим видовим складом для даного типу лісу на ділянках слабкого та помірного рекреаційного впливу, високою участю рудерантів, зокрема адвентивних видів, і порушеним розподілом за ценоморфами на ділянках інтенсивного та середнього рекреаційного впливу. Про суттєву трансформацію свідчить також аналіз спектра життєвих форм, який характеризується збільшенням частки терофітів із посиленням інтенсивності рекреаційного впливу. За структурами надземних пагонів і розміщенням листків домінують безрозеткові трав'яні рослини, підземних пагонів рослини, які не мають спеціалізованих видозмін. За аналізом геліоморф превалюють геліофіти. Аналіз гідротопу показав, що 3 посиленням рекреаційного впливу збільшується частка субмезофітів. Тенденцій щодо зміни ацидоморфічного та нітроморфічного складів не виявлено.

Аналіз фракцій екологічних валентностей показав, що за гігроморфами домінують види геміевривалентної та евривалентної фракції, за шкалою змінності зволоження - гемістеновалентні види, за трофоморфами - гемістенобіонтні види. За відношенням до аерації грунту відсутня евривалентна екологічна фракція. Зафіксовано домінування видів із перехідними групами екологічних стратегій. Серед видів із первинним типом екологічної стратегії превалюють експлеренти. Узагальнена міра фіторізноманіття максимальна в зоні слабкої рекреаційної дигресії.

\section{References}

Aerts, R., \& Honnay, O. (2011). Forest restoration, biodiversity and ecosystem functioning. BMC Ecology, 11, 29.
Antos, J., \& Zobel, D. (1984). Ecological implication of belowground morphology of nine coniferous forest herbs. Botanical Gazette, 145(4), 508-517.

Beckline, M., \& Yujun, S. (2014). Assessing the effectiveness of urban nature reserves on biodiversity conservation. Applied Ecology and Environmental Sciences, 2(6), 130-134.

Brady, L., Hallet, R., Sonti, N., Auyeung, D., \& Lu, J. (2016). Long-term outcomes of forest restorationin an urban park. Restoration Ecology, 24(1), 109-118.

Brygadyrenko, V. V. (2015). Community structure of litter invertebrates of forest belt ecosystems in the Ukrainian steppe zone. International Journal of Environmental Research, 9(4), 1183-1192.

Campione, M., Nagel, L., \& Webster, C. (2012). Herbaceous-layer community dynamics along a harvest-intensity gradient after 50 years of consistent management. Open Journal of Forestry, 2(3), 97-109.

Celesti-Grapow, L., Pysek, P., Jarosik, V., \& Blasi, C. (2006). Determinants of native and alien species richness in the urban flora of Rome. Diversity and Distribution, 12(5), 490-501.

Cooper, A., McCann, T., \& Ballard, E. (2005). The effects of livestock grazing and recreation on irish machair grassland vegetation. Plant Ecology, 181(2), 255-267.

Davies, Z., Edmondson, J., Heinemeyer, A., Leake, J., \& Gaston, K. (2011). Mapping an urban ecosystem service: quantifying above-ground carbon storage at a city-wide scale. Joumal of Applied Ecology, 48, 1125-1134.

Didukh, Y. P. (1994). Fitoindykaciya ekologichnykh faktoriv [Phytoindication of ecological factors]. Naukova Dumka, Kyiv (in Ukrainian).

Dolan, R., Moore, M., \& Stephens, J. (2011). Documenting effects of urbanization on flora using herbarium records. Journal of Ecology, 99, 1055-1062.

Ehrenfeld, J. (2003). Effects of exotic plant invasions on soil nutrient cycling processes. Ecosystems, 6, 503-523.

Ehrenfeld, J., Kourtev, P., \& Huang, W. (2001). Changes in soil functions following invasions of exotic understory plants in deciduous forests. Ecological Applications, 11(5), 1287-1300.

Elliott, K. Vose, J., Knoepp, J., Clinton, B., \& Kloeppel, B. (2015). Functional role of the herbaceous layer in eastern deciduous forest ecosystems. Ecosystems, 18, 221-237.

Farmer, S., Ward, J., Horton, J., \& Clarke, H. (2016). Southern Appalachian urban forest response to three invasive plant removal treatments. Management of Biological Invasions, 7(4), 329-342.

Gamfeldt, L., Snall, T., Bagchi, R., Jonsson, M., Gustafsson, L., Kjellander, P., Ruiz-Jaen, M., Froberg, M., Stendahl, J., Philipson, D., Mikusiński, G., Andersson, E., Westerlund, B., Andren, H., Moberg, F., Moen, J., \& Bengtsson, J. (2013). Higher levels of multiple ecosystem services are found in forests with more tree species. Nature Communications, 4, 1340-1357.

Gibson, D., Adams, E., Ely, J., Gustafson, D., McEwen, D., \& Evans, T. (2000). Eighteen years of herbaceous layer recovery of a recreation area in a mesic forest. Journal of the Torrey Botanical Society, 127(3), 230-239.

Gilliam, F. (2007). The ecological significance of the herbaceous layer in temperate forest ecosystems. BioScience, 57(10), 845-858.

Godefroid, S., \& Koedam, N. (2003). Identifying indicator plant species of habitat quality and invasibility as a guide for peri-urban forest management. Biodiversity and Conservation, 12(8), 1699-1713.

Golay, M., Thompson, J., \& Kolka, R. (2016). Carbon, nitrogen and phosphorus storage across a growing season by the herbaceous layer in urban and preserved temperate hardwood forests. Applied Vegetation Science, 19, 689-699.

Gonrad, H., \& Romane, F. (2005). Long-term evolution of understorey plant species composition after logging in chestnut coppice stands. Annals of Forest Science, 62, 333-342.

Grime, J. P. (1977). Evidence for the existence of three primary strategies in plants and its relevance to ecological and evolutionary theory. The Amercan Naturalist, 111, 1169-1194.

Gunnarsson, B., Knez, I., Hedblom, M., \& Ode Sang, A. (2017). Effects of biodiversity and environment-related attitude on perception of urban green space. Urban Ecosystem, 20(1), 37-49.

Huseinova, R., Kilinc, M., Kutbay, H., Kilic, D., \& Bilgin, A. (2013). The comparison of Grime's strategies of plant taxa in Hacı Osman Forest and Bafra Fish Lakes in the central Black Sea region of Turkey. Turkish Journal of Botany, 37, 725-734.

Jenkins, M., \& Parker, G. (2000). The response of herbaceous-layer vegetation to anthropogenic disturbance in intermittent stream bottomland forests of southem Indiana, USA. Plant Ecology, 151(2), 223-237.

Jukova, L. A., Dorogova, Y. A., Turmahametova, N. V., Gavrilova, M. N., \& Polyanskaya, T. A. (2010). Ekologicheskie shkaly i metody analiza ekologicheskogo raznoobrazija rastenij [Ecological scales and methods for the analysis of ecological diversity of plants]. Mari University Press, YoshkarOla (in Russian).

Karel, M. (1993). Diversity of ecological groups of species in cultural forests of South Bohemia. Ekologia (Bratislava), 12(3), 299-316. 
Kuznetsov, V., Ryzhova, I., Telesnina, V., \& Stoma, G. (2015). Quantitative assessment of the effect of recreation on vegetation, forest litter, and soil compactness in forest parks of Moscow. Moscow University Soil Science Bulletin, 70(1), 17-24.

Ladd, B. (2016). Nitrogen pollution and the meltdown of urban ecosystems. Land, 5, 23.

Lavrov, V. V., Blinkova, O. I., Myroshnik, N. V., \& Ivanenko, O. M. (2015). Synekologichni zasady diagnostyky transformaciji strukturno-funkcional'noji organizaciji lisovyh ekosystem v aspekti evoljuciji [Synecological principles of diagnostic of transformation of structural and functional organization of forest ecosystems in terms of evolution]. Factors of Experimental Evolution of Organisms, 18, 186-190 (in Ukrainian).

Livesley, S., McPherson, E., \& Calfapietra, C. (2016). The urban forest and ecosystem services: Impacts on urban water, heat, and pollution cycles at the tree, street, and city scale. Journal of Environmental Quality, 45, 119-124.

Magurran, A. E. (2004). Measuring biological diversity. Blackwell Publishing, Oxford.

McKinney, M. (2002). Urbanization, biodiversity, and conservation: The impacts of urbanization on native species are poorly studied, but educating a highly urbanized human population about these impacts can greatly improve species conservation in all ecosystems. BioScience, 52(10), 883-890.

Mirkin, B. M., Naumova, L. G., \& Solomeshh, A. I. (2001). Sovremennaja nauka o rastitel'nosti [The modem vegetation science]. Logos, Moscow (in Russian).

Mosyakin, S. L., \& Fedoronchuk, M. M. (1999). Vascular plants of ukraine. A nomenclatural checklist. M.G. Kholodny Institute Botany, Kyiv.

Murat, D., Ender, M., \& Gungor, B. (2008). Plant species recovery on a compacted skid road. Sensors, 8, 3123-3133.

Nagaike, T. (2012). Review of plant species diversity in managed forests in Japan. ISRN Forestry, 2012, 1-7.

Oduber, M., Ridderstaat, J., \& Martens, P. (2015). The connection of vegetation with tourism development and economic growth: A case study for Aruba. Journal of Environmental Science and Engineering, 4, 420-431.

Pickering, C., \& Hill, W. (2007). Impacts of recreation and tourism on plant biodiversity and vegetation in protected areas in Australia. Journal of Environmental Management, 85(4), 791-800.

Polyakov, A. (2009). Kryms'ki liosvi formaciji ta jih ekologichna rol' [Crimea forest formations and their ecological role]. Nove Slovo, Kharkiv (in Ukranian).
Prevosto, B., Kuiters, L., Bernhardt-Römermann, M., Dölle, M., Schmidt, W., Hoffmann, M., Van Uytvanck, J., Bohner, A., Kreier, D., Stadler, J., \& Klotz, S. (2011). Impacts of land abandonment on vegetation: Successional pathways in European habitats. Folia Geobotanica, 46, 303-325.

Raunkiaer, C. (1934). The life forms of plants and statistical plant geography, being the collected papers of Raunkiaer. Clarendon Press, Oxford.

Reier, U., Tuvi, E., Partel, M., Rein Kalamees, R., \& Zobel, M. (2005). Threatened herbaceous species dependent on moderate forest disturbances: A neglected target for ecosystem-based silviculture. Scandinavian Journal of Forest Research, 20(6), 145-152.

Roovers, P., Bossuyt, B., Gulinck, H., \& Hermy, M. (2005). Vegetation recovery on closed paths in temperate deciduous forests. Journal of Environmental Management, 74, 273-281.

Roovers, P., Verheyen, K., Hermy, M., \& Gulinck, H. (2004). Experimental trampling and vegetation recovery in some forest and heath land communities. Applied Vegetation Science, 7, 111-118.

Serebrjakov, I. G. (1962). Jekologicheskaja morfologija rastenij [Ecological plant morphology]. Vyssha Shkola, Moscow (in Russian).

Tarasov, V. V. (2012). Flora Dnipropetrovs'koyi i Zaporiz’koi oblastej [Flora of Dnipropetrovsk and Zaporozhye regions]. Lira, Dnipropetrovsk (in Ukrainian).

Vakhlamova, T., Rusterholz, H., Kanibolotskaya, Y., \& Baur, B. (2016). Effects of road type and urbanization on the diversity and abundance of alien species in roadside verges in Western Siberia. Plant Ecology, 217(3), 241-252.

Vidra, R., Shear, T., \& Stucky, J. (2007). Effects of vegetation removal on native understory recovery in an exotic-rich urban forest. Journal of the Torrey Botanical Society, 134, 410-419.

Wang, Y., Wu, Z., \& Wang, X. (2009). Urban forest landscape patterns in Ma'anshan City, China. International Journal of Sustainable Development and World Ecology, 16(5), 346-355.

Werner, P. (2011). The ecology of urban areas and their functions for species diversity. Landscape and Ecological Engineering, 7(2), 231-240.

Williams, N. S., Morgan, J. W., Mcdonnell, J. W., \& Mccarthy, M. A. (2005). Plant traits and local extinctions in natural grasslands along an urban-rural gradient. Journal of Ecology, 93, 1203-1213. 